\title{
PENGARUH KEAKTIFAN BERORGANISASI DAN PERILAKU BELAJAR TERHADAP PRESTASI AKADEMIK MAHASISWA PENDIDIKAN MATEMATIKA UIN ALAUDDIN MAKASSAR
}

\section{THE EFFECT OF ORGANIZATIONAL ACTIVITIES AND STUDY BEHAVIOR OF ACADEMIC ACHIEVEMENT OF STUDENTS OF MATHEMATICS EDUCATION, UIN ALAUDDIN MAKASSAR}

\author{
Nur Fitriani Safar1), Muhammad Rusydi Rasyid2), Nur Yuliany3) \\ 1,2,3)Fakultas Tarbiyah dan Keguruan Universitas Islam Negeri Alauddin Makassar \\ nurfitrianisafar16@gmail.com ${ }^{11}$, muhammad.rusydi@uin-alauddin.ac.id ${ }^{2}$, nur.yuliany@uin- \\ alauddin.ac.id 3 )
}

\begin{abstract}
Abstrak
Penelitian ini merupakan penelitian Ex-Post Facto yang bertujuan untuk mengetahui pengaruh keaktifan berorganisasi dan perilaku belajar terhadap prestasi akademik mahasiswa pendidikan matematika UIN Alauddin Makassar. Teknik analisis data menggunakan analisis statistik deskriptif presentase dan analisis regresi linier berganda. Hasil analisis deskriptif persentase menunjukan bahwa keaktifan berorganisasi mahasiswa masuk dalam kategori baik dengan persentase $56 \%$, perilaku belajar termasuk dalam kategori baik dengan persentase $68 \%$, dan prestasi akademik termasuk dalam kategori sangat memuaskan dengan interval nilai 3,01 - 3,50. Hasil analisis regresi linier berganda menunjukkan bahwa keaktifan berorganisasi dan perilaku belajar secara bersama-sama berpengaruh secara signifikan terhadap prestasi akademik mahasiswa pendidikan matematika UIN Alauddin Makassar, dengan persamaan regresi $\hat{Y}=3.551$ $0,014 \mathrm{X} 1+0,012 \mathrm{X} 2$ dengan koefisien determinasi $\mathrm{r}^{2}=0,332$. Dari hasil penelitian di atas, maka dapat disimpulkan bahwa terdapat pengaruh keaktifan berorganisasi dan perilaku belajar terhadap prestasi akademik mahasiswa pendidikan matematika UIN Alauddin Makassar.
\end{abstract}

Kata Kunci: keaktifan berorganisasi, perilaku belajar, prestasi akademik

\begin{abstract}
This research is an Ex-Post Facto research that aims to determine the effect of organizational activeness and learning behavior on academic achievement of students of mathematics education at UIN Alauddin Makasssar. Data analysis techniques used descriptive statistical analysis of percentages and multiple linear regresy analysis. Descriptive analysis result showed that the percentage of student activiness in the category of good with a percentage of 56\%, learning behavior included in the good category with a percentage of $68 \%$, and academic achivment included in the category of very satisfying with the interval values of 3.01 - 3.50. The result of multiple linear regression analysis showed that the activeness of organization and learning behavior together significantly influenced the academic achievement of students of mathematics education at Alauddin UIN Makassar, with a regression equation $\hat{Y}=3.551-0.014 X 1+0.012 X 2$ with a coefficient of determination $r^{2}=$ 0.332. from the results of above study, it can be concluded that there is an effect of organizational activeness and learning behavior on academic achievement of mathematics education students at UIN Alauddin Makassar.
\end{abstract}

Keywords: organizational activity, learning behavior, academic achievement 
How to Cite: Safar, N.F., Rasyid, M.R., \& Yuliany, N. (2019). Pengaruh keaktifan berorganisasi dan perilaku belajar terhadap prestasi akademik mahasiswa pendidikan matematika uin alauddin makassar. Al-Asma: Journal of Islamic Education, 2(1), 53-62.

\section{PENDAHULUAN}

Pendidikan merupakan salah satu faktor penting dalam menciptakan sumber daya manusia yang berkualitas. Salah satu langkah yang dapat diambil untuk meningkatkan kualitas sumber daya manusia Indonesia adalah dengan pendidikan atau menuntut ilmu. Pendidikan merupakan salah satu kebutuhan pokok manusia dalam rangka mempertahankan hidup. Pendidikan merupakan hal terpenting untuk membentuk kepribadian manusia (Yaqin dan Santoso, 2016: 172). Dalam dunia pendidikan, menilai merupakan salah satu kegiatan yang tidak dapat ditinggalkan. Menilai merupakan salah satu proses belajar dan mengajar. Di Indonesia, hasil dari kegiatan proses menilai ini dapat kita sebut prestasi akademik atau prestasi belajar.

Prestasi belajar merupakan hasil yang didapat dengan baik pada seorang siswa baik dalam pendidikan atau bidang keilmuan. Prestasi belajar merupakan hasil yang diperoleh individu setelah melakukan proses belajar mengajar dan interaksinya dengan lingkungan (Sulaeman, 2017: 16). Siswa memperoleh presatasi belajar dari hasil yang telah dicapai dari proses belajar. Prestasi belajar merupakan hasil pencapaian yang maksimal menurut kemampuan siswa pada waktu tertentu pada sesuatu yang dipelajari, dikerjakan, dimengerti dan diterapkan (Sulasteri, 2010: 154).

Prestasi akademik adalah seluruh hasil yang telah dicapai yang diperoleh melalui proses belajar akademik yang dapat di pakai sebagai ukuran untuk mengetahui sejauh mana peserta didik menguasai bahan pelajaran yang di ajarkan dan dipelajari. (Maslihah, 2011: 109).

Untuk meraih prestasi akademik yang baik, beberapa orang berpendapat bahwa perlunya memiliki intelegensia yang tinggi sebagai bekal potensi yang akan memudahkan dalam belajar. Kamaluddin dalam (Yusuf, 2013: 125).

Prestasi belajar mahasiswa dapat dilihat dari Indeks Prestasi Kumulatif (IPK) yang diperoleh mahasiswa. Namun, untuk mendapatkan prestasi belajar yang baik bukanlah hal yang mudah, tetapi membutuhkan usaha yang optimal. Meskipun IPK bukan merupakan jaminan kualitas mutlak, namun IPK yang diperoleh mahasiswa selama kuliah biasanya menjadi acuan dalam mengukur prestasi mahasiswa. Hal ini dikarenakan IPK merupakan rata-rata nilai kumulatif yang diperoleh mahasiswa dan atau lulusan suatu program studi. Dengan kata lain, keberhasilan studi sering disamakan dengan nilai IPK yang tinggi. (Manurung, 2017: 18).

Dari beberapa pendapat di atas dapat disimpulkan bahwa prestasi akademik adalah hasil dari kegiatan belajar untuk mengetahui sejauh mana seseorang menguasai pelajaran yang telah di ajarkan.

Prestasi akademik siswa mempunyai keterkaitan dengan perilaku belajar, sebab dalam perilaku belajar mengandung kebiasaan belajar dan cara-cara belajar yang dianut siswa. Perilaku belajar yang baik akan berpengaruh pada hasil belajar yang baik pula. Prestasi belajar dipengaruhi oleh faktor internal salah satunya adalah kebiasaan belajar atau perilaku belajar dan faktor eksternal diantaranya adalah keaktifan berorganisasi. 
Perilaku belajar adalah suatu proses usaha yang dilakukan individu untuk memperoleh suatu perubahan perilaku baru yang secara keseluruhan sebagai hasil pengalaman individu itu sendiri dalam interaksi dengan lingkungannya (Tohirin, 2011: $80)$.

Perilaku belajar sering disebut juga kebiasaan belajar, merupakan dimensi belajar yang dilakukan individu secara berulang-ulang sehingga menjadi otomatis atau spontan. Rampengan dalam (Hanifah, 2001: 69).

Menurut suwardjono dalam (Nugraha, 2013: 14) perilaku belajar yang baik terdiri dari:

a. kebiasaan mengikuti pelajaran

b. kebiasaan membaca buku

c. kunjungan ke perpustakaan

d. kebiasaan menghadapi ujian

Dari uraian di atas disimpulkan bahwa perilaku belajar merupakan kebiasaan belajar seseorang yang dilakukan secara berulang-ulang sebagai hasil dari pengalaman sehingga menjadi otomatis dan spontan.

Mahasiswa yang memiliki kebiasaan belajar yang teratur dalam kesehariannya akan memiliki kemampuan untuk berprestasi lebih baik daripada mahasiswa yang kurang teratur dan hanya belajar menunggu saat menjelang ujian tiba. Mahasiswa yang rajin belajar dan memiliki suatu kebiasaan belajar yang teratur maka prestasi belajar akan bisa diraih semaksimal mungkin. Berbeda dengan mahasiswa yang tidak mempunyai kebiasaan belajar, apabila akan menghadapi ujian mahasiswa tersebut akan belajar lembur atau bahkan tidak belajar sama sekali. Oleh sebab itu, kebiasaan belajar menjadi salah satu faktor penting dalam meningkatkan ataupun menurunnya prestasi belajar (Syah, 2013: 49).

Faktor lain yang mempengaruhi prestasi akademik mahasiswa adalah keaktifan dalam mengikuti kegiatan organisasi di kampus. Organisasi dapat didefenisikan sebagai sekelompok orang yang saling berinteraksi dan bekerja sama untuk merealisasikan tujuan bersama dan tujuan yang telah di tetapkan sebelumnya (Zulfikar, 2015: 22). Organisasi adalah sistem saling pengaruh antar orang dalam kelompok yang bekerja sama untuk mencapai tujuan tertentu (Sutarto, 2006: 40).

Berdasarkan pendapat di atas dapat disimpulkan bahwa organisasi mempunyai tiga elemen yang saling berhubungan yaitu sekelompok orang, kerja sama, dan tujuan. Organisasi adalah upaya untuk memperoleh tujuan organisasi yang telah ditentukan.

Organisasi mahasiswa adalah wahan dan sarana pengembangan diri mahasiswa kearah integritas kepribadian, perluasan wawasan, peningkatan kecendikiawan dan peningkatan kepemimpinan, penalaran, minat, kegemaran, dan kesejahteraan mahasiswa dalam kehidupan kemahasiswaan di perguruan tinggi yang dalam pelaksanaannya dilengkapi dengan perangkat teknis yang jelas dan terencana seperti struktur, mekanisme, fungsi, prosedur, program kerja dan elemen-elemen lainnya yang berfungsi mengarahkan seluruh potensi yang ada dalam organisasi tersebut pada tujuan atau cita-cita yang ingin dicapai (Leny dan Suyasa, 2006: 74).

Organisasi mahasiswa di perguruan tinggi pada dasarnya diselenggarakan atas dasar prinsip dari oleh dan untuk mahasiswa itu sendiri. Organisasi tersebut merupakan wahana dan sarana pengembangan mahasiswa kearah perluasan wawasan peningkatan 
ilmu dan pengetahuan serta integritas kepribadian mahasiswa. Ormawa juga sebagai wadah pengembangan kegiatan ekstrakulikuler mahasiswa di perguruan tinggi yang meliputi pengembangan penalaran, keilmuan, minat, bakat, dan kegemaran mahasiswa itu sendiri (Sudarman, Paryati, 2004: 34).

Bedasarkan uraian di atas maka dapat disimpulkan bahwa kegiatan organisasi kemahasiswaan meliputi pengembangan penalaran, keilmuan, minat, bakat, dan kegemaran yang bisa diikuti mahasiswa ditingkat jurusan, fakultas, dan universitas yang bertujuan untuk memperluas wawasan, ilmu, dan pengetahuan serta membentuk kepribadian mahasiswa.

Salah satu sikap manusia di tentukan oleh pengalaman. Pengayaan pengalaman ditentukan oleh seberapa besar keinginan seseorang terlibat dalam kegiatan sosialkemasyarakatan, atau bagi mahasiswa, kehidupan kampus melalui kegiatan organisasi kemahasiswaan atau sejenisnya, keinginan untuk terlibat dalam organisasi kemahasiswaan sesungguhnya merupakan pemenuhan kebutuhan untuk hidup bermasyarakat (live of society) ataupun kehidupan berkelompok (live of group) (Kementrian Agama RI, 2010: 13). Peran aktif berorganisasi adalah seseorang yang ikut berpartisipasi, terlibat dalam pengambilan keputusan, terlibat dalam memberikan dampak kemajuan atau produktivitas organisasi.

Berbagai cara digunakan oleh para mahasiswa untuk mencari kesuksesan selama menjalani proses perkuliahan. Salah satunya adalah dengan mengikuti satu atau beberapa organisasi yang ada di lingkup kampus, baik itu bersifat ektra kampus maupun intra kampus. Hal tersebut juga didukung oleh pihak kampus yang memberikan wadah para mahasiswanya berupa kegiatan ektra serta intra kulikuler demi menunjang terselenggaranya tugas akademik yang akan dilakukan para mahasiswanya. Namun dalam kenyataannya tidak semua mahasiswa mengikuti kedua program yang diselenggarakan kampus tersebut. Sehingga jenis kegiatan mahasiswa tidaklah sama.

Peran aktif berorganisasi dapat berbentuk loyalitas dan komitmen untuk terlibat pada kegiatan atau program organisasi (Indriana, Widowati, \& Surjawati, 2016: 44).

Mahasiswa aktivis dalam kegiatan organisasi kemahasiswaan adalah mahasiswa yang disamping menekuni aktifitas perkuliahan tapi juga menyempatkan untuk mengikuti aktifitas organisasi kemahasiswaan. Keaktifan organisasi ini biasanya dilandasi oleh bakat, hobi, tuntutan sosial, atau bisa jadi karena pelarian dari aktivitas perkuliahan yang kadang dianggapnya membosankan. Konsekuensi logis dari mahasiswa seperti ini tentunya konsentrasi pemikiran dan waktu akan terbagi menjadi dua, satu sisi pada perkuliahan dan sisi yang lain pada kegiatan organisasi. Kegiatan perkuliahan juga terkadang malah terganggu oleh kegiatan organisasi bahkan ada yang meninggalkannya karena terlalu asyik sehingga terkadang menjadi alasan pembenar bahwa mahasiswa aktivis adalah mahasiswa abadi dan rawan DO. Hal ini disebabkan karena aktifis organisasi memang terkadang memiliki kesibukan yang luar biasa sehingga kegiatan perkuliahan terkadang akan terganggu (Pipin, 2015: 118).

Kegiatan yang diikuti mahasiswa melalui organisasi akan memberikan pengaruh yang kuat terhadap perkuliahannya. Dengan kata lain, keikutsertaan mahasiswa dalam organisasi akan memberikan pengaruh terhadap prestasi akademiknya, dimana mahasiswa diharapkan memiliki prestasi akademik yang lebih baik ketika mereka aktif dalam sebuah organisasi. 
Menjadi aktivis tidaklah berarti menjadikan nilai mata kuliah menjadi turun, justru menjadi aktivis mahasiswa menjadi ajang pembuktian diri kita bahwa kita adalah mahasiswa yang mempunyai nilai lebih dari mahasiswa lain.

Namun, seringkali terdengar dan tidak dapat dipungkiri bahwa kebanyakan seorang aktivis, baik pelajar yang aktif di sekolah maupun mahasiswa yang menjadi aktivis di kampus terkadang mengalami penurunan prestasi akademik di tempat belajarnya. Bahkan, untuk mahasiswa yang menjadi aktivis di kampus terkadang mengenyam bangku kuliahnya lebih lama dari masa studi umumnya. Diantara aktivis di kampus yang belum biasa mensinergikan aktivitas dan akademiknya tidak jarang seorang aktivis terkesan cuek dengan nilai kartu hasil studinya. Mendapat teguran dari pihak dosen tentang ketidakdisiplinan mereka. Para aktivis tidak dituntut untuk memiliki indeks prestasi yang luar biasa dengan peringkat cumlaude, tetapi minimal seorang aktivis memiliki indeks prestasi yang bisa dikatakan standart ataupun bagus.

Berdasarkan penelitian sebelumnya yang dilakukan penelitian ini menjelaskan tentang pengaruh keaktifan berorganisasi dan motivasi belajar terhadap prestasi belajar mahasiswa FE Universitas Negeri Malang. Penelitian ini bertujuan untuk menjelaskan pengaruh keaktifan berorganisasi. Hasil penelitian ini menunjukan bahwa keaktifan berorganisasi mahasiswa mempunyai pengaruh yang negatif terhadap prestasi belajar mahasiswa.

Berdasarkan hasil wawancara yang dilakukan peneliti pada salah satu mahasiswa jurusan Pendidikan Matematika angkatan 2016 yang bernama Fairus Ismail, mengatakan bahwa dia adalah seorang organisatoris yang mulai aktif organisasi intra kampus dan ekstra kampus pada semester 2 sampai sekarang. Pada saat semester 2 Indeks Prestasi yang di dapatkan adalah 3,8 kemudian pada semester selanjutnya terjadi penurunan indeks prestasi menjadi 3,2. Berdasarkan hasil wawancara di atas dapat diasumsikan keaktifan berorganisasi mempengaruhi prestasi akademik mahasiswa.

Selain itu peneliti juga melakukan pengamatan awal tentang perilaku belajar mahasiswa pendidikan matematika, hasil pengamatan awal peneliti melihat perilaku belajar mahasiswa sudah baik. hal ini terlihat dari mahasiswa yang mendengarkan dengan baik penjelasan dari dosen yang mengajar. Namun hasil belajar mahasiswa belum maksimal hal ini terlihat dari indeks prestasi mahasiswa, masih ada mahasiswa yang mempunyai IPK dibahawah 3,50 bahkan ada beberapa mahasiswa yang mempunyai IPK di bawah 3,00. Peneliti juga melakukan wawancara dengan salah satu mahasiswa yang mempunyai IPK di bawah 3,00 yaitu Muh.Adlansyah.R. Dari hasil wawancara tentang beberapa komponen perilaku belajar, diketahui bahwa mahasiswa tersebut selalu mengikuti pelajaran pada saat perkuliahan akan tetapi dia sering terlambat pada saat akan mengikuti pelajaran, mahasiswa tersebut juga mengaku hampir tidak pernah membaca buku teksnya ketika ada waktu luang dan tidak pernah belajar meskipun akan menghadapi ujian. Berdasarkan wawancara tersebut diasumsikan bahwa perilaku belajar berpengaruh terhadap prestasi akademik mahasiswa.

Dari uraian di atas maka memerlukan adanya penelitian yang bertujuan untuk mengetahui pengaruh keaktifan berorganisasi dan perilaku belajar terhadap prestasi akademik mahasiswa UIN Alauddin Makassar. 


\section{METODE PENELITIAN}

Penelitian ini menggunakan desain penelitian expost facto. Variabel yang diselidiki dalam penelitian ini terbagi dalam dua jenis, yaitu variabel bebas dan variabel terikat. Variabel bebasnya adalah keaktifan berorganisasi (X1) dan perilaku belajar (X2), sedangkan variabel terikatnya prestasi akademik (Y). Populasi dalam penelitian ini adalah mahasiswa pendidikan matematika UIN Alauddin Makassar yang terdiri dari angkatan 2016, 2017, dan 2018 yang berjumlah 230 orang. Metode pengambilan sampel yang digunakan adalah stratified random sampling dengan jumlah sampel 57 orang, 25\% dari total populasi. Penelitian ini menggunakan dua jenis instrumen yaitu angket dan dokumentasi. Data yang diperoleh dianalisis dengan menggunakan menggunakan teknik analisis statistik, yaitu statistik deskriptif dan analisis regresi linier berganda.

\section{HASIL DAN PEMBAHASAN}

\section{Analisis Statitistik Deskriptif Persentase}

Berikut ini adalah tabel hasil analisis deskriptif persentase data pengaruh keaktifan berorganisasi dan perilaku belajar terhadap prestasi akademik mahasiswa Pendidikan Matematika UIN Alauddin Makassar.

Tabel 1. Deskriptif Presentase Keaktifan Berorganisasi

\begin{tabular}{clcccc}
\hline No & \multicolumn{1}{c}{ Indkator } & $\begin{array}{c}\text { Skor Hasil } \\
\text { Penelitian }\end{array}$ & $\begin{array}{c}\text { Skor } \\
\text { Ideal }\end{array}$ & Persentase & Kategori \\
\hline 1 & Kedisiplinan berorganisasi & 635 & 1140 & $55 \%$ & Baik \\
\hline 2 & $\begin{array}{l}\text { Tanggung jawab dalam } \\
\text { berorganisasi }\end{array}$ & 730 & 1140 & $64 \%$ & Baik \\
\hline 3 & $\begin{array}{l}\text { Berpendapat dalam } \\
\text { berorganisasi }\end{array}$ & 873 & 1596 & $54 \%$ & Baik \\
\hline 4 & $\begin{array}{l}\text { Keterlibatan melaksanakan } \\
\text { kegiatan }\end{array}$ & 997 & 1824 & $54 \%$ & Baik \\
\hline $\begin{array}{c}\text { Rata- } \\
\text { rata }\end{array}$ & & & $56 \%$ & Baik \\
\hline
\end{tabular}

Dari tabel 1 menunjukkan bahwa keaktifan berorganisasi indikator kedisiplinan mendapat skor 55\% termasuk dalam kategori baik, hal ini berarti sikap mahasiswa dalam mengikuti organisasi sudah sesuai dengan peraturan-peraturan yang berlaku dalam organisasi tersebut. Pada indikator tanggung jawab skor hasil penelitian sebesar $64 \%$ termasuk dalam kategori baik. Hasil tersebut menunjukan bahwa sikap mahasiswa dalam berorganisasi sudah mampu menjalankan amanah, tugas-tugas dan tanggung jawabnya dalam berorganisasi. Indikator berpendapat dalam organisasi menunjukan nilai persentase sebesar $54 \%$, artinya mahasiswa dalam berorganisasi sudah mampu memberikan saran dan kritik untuk kemajuan organisasi tersebut. Pada Indikator keterlibatan dalam organisasi menunjukan nilai persentase sebesar 54\%, hal tersebut menunjukan bahwa mahasiswa tersebut termasuk dalam mahasiswa yang cukup aktif dalam kegiatan organisasi. 
Tabel 2. Deskriptif Presentase Perilaku Belajar

\begin{tabular}{cccccc}
\hline No & Indkator & $\begin{array}{c}\text { Skor Hasil } \\
\text { Penelitian }\end{array}$ & $\begin{array}{c}\text { Skor } \\
\text { Ideal }\end{array}$ & Persentase & Kategori \\
\hline 1 & Kebiasaan mengikuti pelajaran & 1680 & 2280 & $73 \%$ & Baik \\
\hline 2 & Kebiasaan membaca buku teks & 1003 & 1596 & $62 \%$ & Baik \\
\hline 3 & Kebiasaan mengerjakan tugas & 476 & 684 & $69 \%$ & Baik \\
\hline 4 & Kebiasaan melaksanakan tugas & 816 & 1140 & $71 \%$ & Baik \\
\hline $\begin{array}{c}\text { Rata- } \\
\text { rata }\end{array}$ & & & $68 \%$ & Baik \\
\hline
\end{tabular}

Dari tabel 2 menunjukkan bahwa perilaku belajar dengan indikator mengikuti pelajaran mendapat skor $73 \%$ termasuk dalam kategori baik, dimana pada gambar histogram terlihat bahwa persentase indikator kebiasaan mengikuti pelajaran adalah persentase paling tinggi diantara indikator yang lain. Hal ini menunjukan bahwa kebiasaan mahasiswa dalam mengikuti pembelajaran seperti kehadiran dan keaktifan pada proses belajar mengajar sudah mendekati maksimal dilihat dari persentasenya yang sudah mendekati skor ideal. Mahasiswa cenderung aktif pada saat pembelajaran dan menanggapi pertanyaan yang diajukan oleh dosen. Pada indikator kebiasaan membaca buku skor hasil penelitiannya sebesar $62 \%$ dan termasuk dalam kategori baik. Hal ini berarti kebiasaan mahasiswa dalam membaca buku pelajaran maupun berkunjung ke perpustakaan sudah cukup baik. Namun meskipun termasuk dalam kategori baik, dalam gambar histogram di atas terlihat bahwa persentase indikator kebiasaan membaca mempunyai persentase paling rendah diantara indikator yang lainnya. Pada indikator kebiasaan mengerjakan tugas skor hasil penelitiannya sebesar 69\%. Hal ini menunjukan bahwa mahasiswa sudah mampu mengerjakan tugas denga baik dan benar baik itu tugas mandiri atau pun tugas kelompok selain itu mahasiswa juga mengerjakan tugas dengan usahanya sendiri. Pada indikator kebiasaan melaksanakan ujian skor hasil penelitiannya sebesar 71\%. Hal ini menunjukan bahwa kebiasaan mahasiswa dalam melaksanakan ujian seperti belajar sebelum ujian dan tidak mencontek pada saat ujian sudah cukup baik, artinya saat mengahadapi tes atau ujian mahasiswa akan mempersiapkan diri dengan belajar dengan maksimal.

Tabel 3. Analisis Deskriptif Presentase Prestasi Akademik

\begin{tabular}{ccccc}
\hline No & Indeks Prestasi & Kategori & Frekuensi & Persentase (\%) \\
\hline 1 & $3,51-4,00$ & Cumlaude & 24 & 42 \\
\hline 2 & $3,01-3,50$ & Sangat memuaskan & 28 & 49 \\
\hline 3 & $2,76-3,00$ & Memuaskan & 5 & 9 \\
\hline & Jumlah & & 57 & 100 \\
\hline
\end{tabular}

Berdasarkan tabel di atas, dapat disimpulkan bahwa prestasi akademik mahasiswa jurusan pendidikan matematika UIN Alauddin Makassar dapat digolongkan dalam kategori yang memuaskan karena setetlah diolah ternyata terdapat 24 mahasiswa yang prestasi akademiknya masuk dalam kategori cumlaude dengan persentase sebanyak $42 \%$, sebanyak 28 mahasiswa yang prestasi akademiknya termasuk dalam kategori sangat memuaskan dengan persentase sebanyak 49\%, dan sebanyak 5 mahasiswa yang prestasi akademiknya termasuk dalam kategori memuaskan dengan persentase sebanyak $9 \%$. 


\section{Analisis Regresi Linier Berganda Uji Asumsi Klasik}

Uji Normalitas terhadap residual dari variabel bebas dan variabel terikat dengan uji Kolmogorof-Smirnof menunjukkan nilai signifikan 0,2 >0,05 yang artinya residual berdistribusi normal.

Uji multikolinearitas, dari hasil pengujian dengan SPSS diketahui bahwa nilai toleransi semua variabel independen terhadap variabel dependen yaitu keaktifan berorganisasi (X1) dan perilaku belajar (X2) mempunyai nilai tolerance 0,948 $>0,10$ dan VIF $1,055<10$ sehingga model regresi tidak mengandung multikolinieritas.

Uji Heterokedastisitas, dari hasil pengujian dengan SPSS menggunakan grafik scatterplot, terlihat bahwa titik-titik pada diagram scatterplot menyebar secara acak di atas maupun di bawah angka 0 sumbu Y. Hal ini dapat disimpulkan bahwa model regresi yang diperoleh dalam penelitian ini tidak terjadi heteroskedestisitas, sehingga model regresi layak dipakai untuk memprediksi variabel dependen berdasarkan masukan dari variabel independen.

\section{Uji Hipotesis}

Tabel 4. Uji Hipotesis

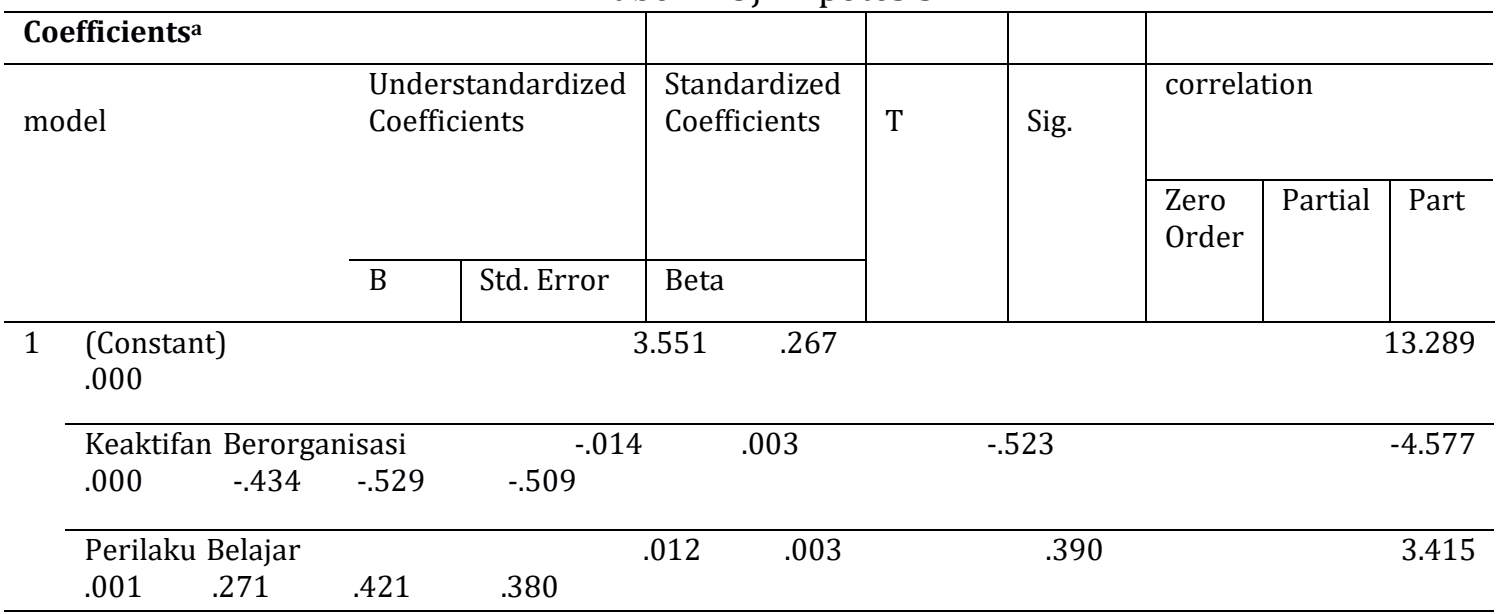

Uji hipotesis dilakukan untuk untuk mengetahui apakah keaktifan berorganisasi dan perilaku belajar berpengaruh terhadap prestasi akademik mahasiswa pendidikan matematika UIN Alauddin Makassar. Berdasarkan output SPSS diketahui bahwa t hitung untuk variabel keaktifan berorganisasi sebesar -4.577 dengan probabilitas $0,000<0,05$ yang artinya signifikan. Didapatkan t tabel dari db 54 pada taraf signifikansi $5 \%$ adalah 2,005. Nilai t hitung -4.557 dalam analisis regresi linier berganda berarti berpengaruh negatif. Hal ini menunjukkan bahwa secara parsial ada pengaruh negatif yang signifikan antara keaktifan berorganisasi terhadap prestasi akademik mahasiswa jurusan pendidikan matematika UIN Alauddin Makassar. Untuk t hitung variabel perilaku belajar sebesar $3.415>2.005$ dengan probabilitas 0,001 < 0,05 yang berarti bahwa variabel perilaku belajar secara parsial berpengaruh signifikan terhadap prestasi akademik mahasiswa jurusan pendidikan matematika UIN Alauddin Makassar. 
Tabel 5. Uji ANOVA

\begin{tabular}{|c|c|c|c|c|c|c|}
\hline \multicolumn{7}{|c|}{ ANOVAa } \\
\hline \multicolumn{2}{|c|}{ Model } & Sum of Squares & Df & Mean Square & $\mathrm{F}$ & Sig. \\
\hline \multirow[t]{3}{*}{1} & Regression & 1.693 & 2 & .846 & 13.449 & $.000^{\mathrm{b}}$ \\
\hline & Residual & 3.398 & 54 & .063 & & \\
\hline & Total & 5.091 & 56 & & & \\
\hline \multicolumn{7}{|c|}{ a. Dependent Variable: prestasi akademik } \\
\hline \multicolumn{7}{|c|}{ b. Predictors: (Constant), perilaku belajar, keaktifan berorganisasi } \\
\hline
\end{tabular}

Berdasarkan hasil uji simultan seperti pada tabel diperoleh $\mathrm{F}$ hitung sebesar 13.449 dan F tabel 3.16 diperoleh dari Df1 = jumlah variabel bebas yaitu 2, dan jumlah responden yaitu $57-2=55$ sehingga $(13.449>3.16)$ dengan probabilitas $0,000<0,05$ yang berarti signifikan. Dengan demikian ada pengaruh yang signifikan antara keaktifan berorganisasi dan perilaku belajar terhadap prestasi akademik mahasiswa pendidikan matematika UIN Alauddin Makassar.

Tabel 6. Summary

\begin{tabular}{|c|c|c|c|c|}
\hline \multicolumn{5}{|c|}{ Model Summaryb } \\
\hline Model & $\mathrm{R}$ & R Square & Adjusted R Square & Std. Error of the Estimate \\
\hline 1 & .577 & .332 & \multicolumn{2}{|r|}{.25085} \\
\hline \multicolumn{5}{|c|}{ a. Predictors: (Constant), perilaku belajar, keaktifan berorganisasi } \\
\hline \multicolumn{5}{|c|}{ b. Dependent Variable: prestasi akademik } \\
\hline
\end{tabular}

Berdasarkan tabel tampak bahwa nilai R square sebesar 0,332 yang berarti bahwa variabel keaktifan berorganisasi dan perilaku belajar berpengaruh terhadap prestasi akademik mahasiswa pendidikan matematika UIN Alauddin Makassar sebesar 33,20\% sedangkan $66.80 \%$ dipengaruhi faktor lain di luar faktor keaktifan berorganisas dan perilaku belajar.

\section{SIMPULAN}

Berdasarkan hasil penelitian dan pembahasan dapat diketahui bahwa 1) Keaktifan berorganisasi mahasiswa Pendidikan Matematika UIN Alauddin Makassar termasuk dalam kategori baik dengan persentase 56\%. Perilaku belajar mahasiswa Pendidikan Matematika UIN Alauddin Makassar termasuk dalam kategori baik dengan persentase 68\%. Prestasi akademik mahasiswa Pendidikan Matematika UIN Alauddin Makassar termasuk dalam Kategori sangat memuaskan dengan interval inilai 3,01 - 3,50. 2) Keaktifan berorganisasi berpengaruh negatif secara signifikan terhadap prestasi akademik mahasiswa jurusan Pendidikan Matematika UIN Alauddin Makassar artinya prestasi akademik mahasiswa jurusan pendidikan matematika UIN Alauddin Makassar akan mengalami penurunan apabila terjadi kenaikan pada keaktifan berorganisasi. Prestasi akademik akan meningkat jika terjadi penurunan pada keaktifan berorganisasi. 3) Perilaku belajar berpengaruh positif secara signifikan terhadap prestasi akademik mahasiswa jurusan pendidikan matematika UIN Alauddin Makassar artinya prestasi akademik akan meningkat apabila 
perilaku belajar meningkat. Sedangkan prestasi akademik akan menurun apabila perilaku belajar juga menurun. 4) Keaktifan berorganisasi dan perilaku belajar secara bersamasama berpengaruh signifikan terhadap prestasi akademik mahasiswa jurusan pendidikan matematika UIN Alauddin Makassar.

\section{DAFTAR PUSTAKA}

Hanifah. (2001). Pengaruh Perilaku Belajar terhadap Prestasi Akademik mahasiswa akuntansi, Media riset Akuntansi, 1, 63-68.

Indriana, D. T., Widowati, A. I., \& Surjawati. (2016). Faktor-Faktor Yang Mempengaruhi Prestasi Akademik: Studi Kasus Pada Mahasiswa Program Studi Akuntansi Universitas Semarang. Dinamika Sosial Budaya, 18(1), 39-48.

Isa Ulinuha Ainul Yaqin, Sigit Santoso, S. (2016). Pengaruh Keaktifan Berorganisasi Terhadap Kompetensi Interpersonal Mahasiswa Pendidikan Akuntansi FKIP UNS Tahun 2016, 2(2), 171-189.

Keagamaan, K. agama R. badan L. dan D. P. K. (2010). Toleransi Beragama Mahasiswa. Jakarta: Maloho Jaya Abadi Press.

Maslihah, S. (2011). Studi Tentang Hubungan Dukungan Sosial, Penyesuaian Sosial Di Lingkungan Sekolah Dan Prestasi Akademik Siswa Smpit Assyfa Boarding School Subang Jawa Barat. Jurnal Psikologi Undip, 10(2), 103-114. http://doi.org/10.14710/jpu.10.2.103-114

Nugraha, A. P. (2013). pengaruh kecerdasan emosional dan perilaku belajar terhadap tingkat pemahaman akuntansi.

Pipin. (2015). Dinamika Organisasi Mahasiswa Ekstra Kampus IAIN Sunan Ampel Surabaya.

Sulaeman, A. (2017). Pengaruh Keaktifan Mahasiswa Dalam Mengikuti Organisasi Himpunan Mahasiswa Pendidikan Administrasi Perkantoran Dan Disiplin Belajar Terhadap Prestasi Belajar Mahasiswa Program Studi Pendidikan Administrasi Perkantoran Fakultas Ekonomi UNY.

Sulasteri, S. (2010). Faktor-faktor yang mempengaruhi prestasi belajar mahasiswa jurusan pendidikan matematika fakultas tarbiyah dan keguruan uin alauddin makassar, jurnla MaPan vol 1 no 1, 151-177.

Sutarto. (2006). Dasar-Dasar Organisasi. Yogyakarta: Gadjah Mada University Press.

Syah, M. (2013). Manajemen pendidikan. Surakarta: Lembaga Pengembangan Pendidikan (LPP) dan UPT UNS Pres.

Tohirin. (2011). Psikologi Pembelajaran Pendidikan Agama Islam. Jakarta: PT. Raja Grafindo Persada.

Zulfikar, M. I. (2015). Hubungan Antara Keaktifan Kegiatan Dalam Organisasi di Kampus dengan Kompetensi Sosial Calon Guru Pada Mahasiswa Jurusan Pendidikan Bahasa Jerman Fakultas Bahasa dan Seni Universitas Negeri Yogyakarta. 